\title{
Pipe Dreams: Urban Wastewater Treatment for Biodiversity Protection
}

\author{
Caitlin Cunningham ${ }^{1, *}$ and Mohammad Gharipour ${ }^{2}$ \\ 1 Graduate Landscape Architecture Program, Morgan State University, Baltimore, MD 21251, USA \\ 2 Graduate Architecture Program, Morgan State University, Baltimore, MD 21251, USA; \\ mohammad.gharipour@morgan.edu \\ * Correspondence: cait.cunningham@gmail.com; Tel.: +1-410-967-4659
}

Received: 21 December 2017; Accepted: 25 January 2018; Published: 30 January 2018

\begin{abstract}
Wastewater treatment systems in urban areas of the United States have reached a critical replacement age. From century-old, deteriorating systems raw sewage overflows into basements, streets and surface waters. In economically depressed cities, sewage overflows are frequent and heavily fined, costing municipalities millions of dollars. Pollution by untreated wastewater severely degrades aquatic and wetland ecosystems and exacerbates serious risks to public health. Necessary and extensive clean water infrastructure repairs are imperative to protect the health and habitat of humans and other organisms. As accelerating human development contributes to wide spread losses of naturally occurring wetlands, dwindling patches of habitat native plant and animal species rely on for survival are further threatened. Within this alarming situation is an opportunity to rebuild and retrofit our wastewater treatment systems with infrastructure that enhances long-term ecosystem sustainability.
\end{abstract}

Keywords: urban wastewater treatment; constructed wetlands; habitat loss

\section{Introduction}

Below the streets of most major urban areas of the United States water infrastructure, including drinking water and wastewater treatment systems, is in a state of widespread disrepair. In many cities pipe failures and raw sewage overflows are frequent and substantial, the result of deteriorating 19th century conveyance structures. In Baltimore, Maryland water infrastructure conveyance pipes burst approximately one thousand times a year. Nearly twenty percent of the water piped from reservoirs for Baltimore's drinking water is lost from leaky pipes before it can even be consumed [1]. In Houston, Texas forty percent of conveyance pipes are in need of replacement. Excessive heat waves and a long period of drought led to eleven thousand pipe ruptures in 2011, costing Houston one quarter of its existing clean water resources for that year. In Miami, Florida sewage pipes have failed approximately sixty-five times between 2009 and 2011, polluting streets and waterways with over 47 million gallons of raw sewage [2]. In Baltimore, heavy rain events cause frequent sewage overflows into local streets and water bodies from leaky conveyance pipes while wastewater treatment plants discharge raw sewage from relief valves located on streams. Homes adjacent to sewage overflows in Baltimore are at times flooded with raw sewage during major storms while local waterways are contaminated to such an extent that zero human contact is advised. Limited signage or contribution to public awareness by Baltimore city agencies has put citizens and tourists at risk of contracting waterborne diseases [3].

Deleterious effects of water pollution by sewage coming from large urban areas are of increasing concern. Sewage overflows contribute to excessive nutrient pollution that feeds harmful algal blooms. Harmful algal blooms suffocate organisms by blocking light and depleting oxygen sometimes producing hypoxic dead zones where no plant or animal life can survive. Harmful algal blooms 
can cause illnesses in human and animals by direct contact or by exposure to toxic algal bacteria contamination in drinking water or seafood. In 2014 city officials of Toledo, Ohio warned residents against contact with municipal drinking water due to a three hundred square mile algal bloom in Lake Erie that caused levels of bacterial toxicity surpassing the capacity of the city's treatment plants [4]. Drinking water contaminated by harmful algal blooms can cause severe stomach flu-like symptoms, neurological damage and in some cases death from liver toxicity [5]. The pollution of waterways with wastewater contributes to: decreased life and biodiversity in aquatic ecosystems, proliferation of harmful bacterial diseases and loss of critical carbon storage in our oceans. Ultimately, ecosystems that provide water resources we rely on in order to live on are in danger of collapse as a result of increasing development and anthropogenic pollution of the environment [6].

Approximately half of the terrestrial space left on earth has been altered by human clearing and development, precipitating wide spread loss of species diversity [7]. Efforts to retain native species are critical to maintaining our native ecosystems, ecosystems that support human communities by supplying services like water purification, protection from natural disasters and pollination of crops. Native species are the support systems for the ecosystem services critical to human survival. Urbanization is the fastest growing type of land-use worldwide and one of the most destructive land-use types to local ecosystems, contributing to accelerated extinction of native species [7]. There is a vital need to conserve our native species while appreciating opportunities provided within the novel and diverse ecosystems that comprise our urban environments [8]. What can be done in an urban context to increase resiliency and ecosystem health and to protect our water bodies from collapse? Two ecological concepts provide a theoretical foundation for sustainable improvements to urban wastewater treatment systems. Reconciliation ecology, as articulated by ecologist Michael Rosenzweig, is the concept of consciously planning shared habitats for humans and wildlife in order to mitigate loss of biodiversity [9]. Closely related to reconciliation ecology is the concept of urban ecological mutualism [10]. Coined in 2008 by urban planner and landscape architect Brooke Ray Smith, urban ecological mutualism depends on a critical departure from a linear waste creation and disposal paradigm to a closed-loop resource paradigm. In closed-loop resource systems, waste that is created is repurposed without the creation of additional waste for the lifetime of the material. For the purposes of wastewater treatment, urban ecological mutualism refers to treatment and conveyance methods that have positive impacts on both humans and wildlife [10]. The design of urban clean water infrastructure, defined as the combination of drinking and wastewater infrastructure, has historical precedence dating back to Roman times. The clean water infrastructure of most US cities relies on large quantities of fresh water to produce food and products and to manage human, industrial and agricultural waste. Water clean enough to wash a baby is currently used to flush our toilets and wash our cars. An enormous amount of energy is required to convey and treat wastewater in our current water paradigm of usage and release. Innovations integrating the reuse of water, including wastewater systems that rely on reuse or treatment of used but not contaminated "gray water" on-site can make efficient use of a nominal resource [11]. Most of our current treat and release systems built with ubiquitous hard "grey" infrastructure do little to support ecological health while discharging pollution, increasing sedimentation and replacing habitat to the detriment of human and ecosystem health. An overall reimagining and redesign of current clean water infrastructure is necessary to address a state of disrepair and the increasing impacts of climate change on the hydrologic cycle, including heavier rains and increasing droughts. "Green" infrastructure systems that treat wastewater effectively and remove anthropogenic pollutants are modeled after naturally occurring systems such as wetlands. Constructed wetlands are artificially designed natural filters offering ecologically beneficial treatment to polluted waters released from anthropogenic sources.

The following review of literature in conservation ecology, landscape architecture and environmental management seeks to illuminate inadequacies in existing systems that treat and release wastewater coming from dense urban areas of the United States. Brief historical precedence of the formation of existing systems is given to provide a foundation of understanding wastewater 
infrastructure development in the majority of urban areas in the U.S. and the state of these systems as they exist today. An examination of literature regarding ecological strategies for the conservation of biodiversity in human dominated regions provides a conceptual framework for the use of green infrastructure to protect vulnerable ecosystems. Further examination of literature concerning current conservation and green infrastructure planning strategies and their relationship to human health was performed in order to assess the overall feasibility of land-based wastewater infrastructure in urban regions. Finally, a case study of existing wastewater treatment infrastructure is presented alongside case studies of constructed wetland wastewater treatment systems in order to illustrate potential outcomes of green, land-based wastewater treatment.

\section{A Brief History of Wastewater Infrastructure}

The practice of discharging human waste into surrounding water bodies is likely as old as the first human settlements. Historically, wastewater is managed by using gravity to discharge wastewater directly or indirectly into topographical lowlands, to areas where wetlands already existed or exist as a result [12]. Advanced wastewater treatment methods date back to the early pipe filters and sewage canals of Indus Valley settlements in 26-1700 BCE. The complex, extensive sewer networks of ancient Rome separated water resources into aqueducts and included many smaller networks to drain sub-regions of their wastewater. Public baths and latrines were constructed to dissuade people from using the streets for disposal. Simultaneously, wetlands were drained for to erect Roman city foundations [13].

Following the fall of the Roman Empire, a dark age of limited and inadequate sanitation persisted in European countries and the United States for a period of nearly a thousand years. In urban areas of the early nineteenth century United States and much of the developed world, raw sewage from homes was dumped into public cesspools that were left to fester and breed disease before collection by sewage workers [13]. By the mid-19th century an abundance of water could be piped into homes, only to be later flushed out into human waste cesspools, causing frequent overflows and further spreading waste and disease. Sanitary engineers advocated for a solution in flush-based pipe connections from that would move water and waste from public cesspools to local water bodies. Throughout the twentieth century convenient water bodies were explicitly relegated to the role of wastewater dumps, reflecting an implicit idea that the "streams are nature's sewers", [14]. In 1854, the British physician John Snow proved outbreaks of waterborne diseases were the result of contaminated water supplies from leaking sewage pipes. Following Snow's correlation of disease and raw sewage contamination, cities in the United States took on massive sewage conveyance projects to protect potable water sources. Massive engineered sewer networks were built to address enormous excrement increases following the rapid growth of cities and industry in 19th century Britain and the United States. Developing modern sewer systems meant a large-scale transformation of native hydrology, not unlike historical Roman water infrastructure [14]. The replacement of cesspools and stagnant alley ponds carrying bacterial diseases required significantly greater volumes of flushable water. Continuous clean water pouring from taps meant greater demand for fresh water from reservoirs, requiring massive dams and further environmental disruption [15]. In order to install a comprehensive sewage system at that time in the low-lying city of Chicago it was necessary to raise most of the city with thousands of jackscrews to install sewer pipes that could convey wastewater with enough gravity [16]. At the time, common knowledge dictated water had the ability to "purify itself" of sewage and industrial pollution. The solution to the issue of water pollution and the threat of disease was dilution. This philosophy of dilution paved the way for the flush-based mechanisms of our modern waste removal infrastructure [14].

The importance of wastewater management to public health cannot be understated. Mortality rates in the US lowered by 40\% from 1900 to 1940, partially as a result of rapid decreases in diseases transmitted via sewage [14]. Elsewhere bacterial diseases continue to cause public health devastation through the contaminated water supplies of countries with inadequate or damaged sanitation systems, 
such as in Haiti and Ghana. The Clean Water Act of 1972 was passed in the United States as part of a growing effort to reduce the amount of pollution entering waterways. The Clean Water Act necessitated the construction of numerous new wastewater treatment facilities in order to meet more rigorous water quality standards and the added demands of growing populations and. Many of the plants built following the Clean Water Act are long overdue to be updated with "add-on processes" necessary to meet pollution loading regulations [17]. Pollution reductions currently mandated by the Environmental Protection Agency as an effort to meet the goals of the Clean Water Act have led to heavy fines in municipalities that lack adequate resources to repair their crumbling sewage infrastructure. The economic cost of updating failing systems is often prohibitive to the repair of inadequate systems. In the United States, large-scale wastewater infrastructure is now reaching "replacement age", a crisis level state of disrepair in many cities that lack the resources for rebuilding [3]. As our century-old systems in the US fail during a time of limited financial means alternative systems and add-on processes are imperative to protect clean water resources and our ecosystems; and to prevent human contact with disease.

\section{Strategies for Ecosystem and Clean Water Protection: Ecological Mutualism and Reconciliation}

Mutualism is an ecological term referring to a species interaction wherein both or all species benefit. In the work of ecological urban planner Brook Ray Smith, the term urban ecological mutualism is defined as a model of urban ecosystems wherein infrastructure is more self- sustaining and less defined by systems of conveyance and linear disposal. Mutualistic ecosystems ideally operate in closed loop-systems where all wastes produced are repurposed [10]. For example, Phosphorus is one of the most difficult nutrients to remove from wastewater [18]. The industrial byproducts alum sludge (a byproduct of drinking water purification) and oyster shells (a landfill problem in Korea) were captured from the linear waste stream and used to purify industrial discharge in constructed wastewater treatment wetlands in a study performed at the Korean Institute of Water and Environment in 2007. The repurposed media of alum sludge and oyster shells filtered and removed Phosphorus effectively [18]. Alum sludge removed significant phosphorus in another study performed in Ireland in 2009 at the Centre for Water Resources Research [19]. The measurement of an effective design incorporating urban ecological mutualism is the extent to which humans and other species communities benefit from the shared landscape over time. Infrastructure design incorporating this concept requires an emphasis on resource optimizing and energy-usage minimizing, especially in repurposing waste as a resource. In ecologically mutual wastewater treatment systems, waste is repurposed as a resource [10]. Wastewater filtered through constructed wetlands can irrigate crops, parks, gardens, or golf courses [20]. The organization Metropolitan Water Reclamation District of Greater Chicago is now capturing phosphorus from wastewater to sell as a high-quality fertilizer. A large wastewater treatment in suburban Chicago extracts captured phosphorus and sells it to a company to turn it into non-water-soluble fertilizer that fertilizes only when the plant releases acids to signal its need, reducing phosphorus runoff concentrations. Encouragingly, the selling of phosphorus from waste treatment will net the district around two million dollars per year. A retrofit to perform the capture is thirty million dollars, meaning a fifteen-year return on the investment and a significant percentage of phosphorus being converted into a reclaimed fertilizer. According to David St. Pierre the director of the Metropolitan Water Reclamation District of Greater Chicago: "we [should be] moving from a waste paradigm to a resource paradigm", [21].

Urban ecological mutualism is an ideal outcome of systems designed in accordance with the principle of reconciliation ecology. The ecologist Michael L. Rosenzweig articulated the term reconciliation ecology in 2003 as the science and practice of reconciling human use of the earth with that of other species in order conserve species diversity. According to Rosenzweig, setting aside land for habitat reserves is inadequate to mitigate massive conservation losses. Large-scale habitat networks in direct contact with human environments are necessary to prevent further losses of biodiversity. It is important for landscape designers to work in tandem with ecologists to interpret studies gathered 
in nature reserves that indicate the habitat necessities of specific species. Using green infrastructure in wastewater treatment has the potential to accommodate the needs of various native species [9]. Wildlife corridors, for example, are of vital importance in developing urban habitats that offer benefits to both humans and wildlife. Wildlife corridors are generally located along streams in urban areas and allow the passage of species from isolated patches into neighboring habitats to ensure long-term species reproduction and survival. Greenways are trails connecting humans in urban areas to networks of green spaces and are used both for recreation and commuting. Wildlife corridors along streams often operate as both habitat links and human pathways, they provide a mutually beneficial public health service to citizens along with the connectivity necessary for the survival of species diversity [22]. Because sewage overflows are most often deposited into streams due to their gravity-dependent design, the prevention of such overflows is important to developing these multi-functional corridors in urban areas. Repairs to current gravity-fed centralized wastewater treatment systems are necessary to protect existing wildlife corridors and greenways. There is potential for retrofits to existing low-lying wastewater valves in streams to redirect sewage overflows to adjacent treatment areas and away from sensitive stream ecosystems, reducing the length of conveyance pipes (and conveyance repairs) necessary to redirect overflows to centralized treatment areas.

A paradigm shift to infrastructure with ecologically beneficial design would benefit people by lowering infrastructure costs for municipalities in the United States. In the highly developed (40\% urbanized) Capital Region of Minnesota, frequent flooding from storm water and sewage overflows have necessitated new storm and sewage water management infrastructure to control excessive pollution inundation of surface waters. The city decided against a standard sewage pipe collection system costing approximately two and a half million dollars in favor of an approximately two-million-dollar green infrastructure system. The green infrastructure system consists of eight decentralized land-based storm water management designs including underground storage and infiltration facilities, a storm water pond and rain gardens [23]. Installing landscapes as infrastructure is a way to lower energy costs, to retrofit existing infrastructure and to replace the need for more expensive gray infrastructure construction and maintenance. According to the Environmental Protection Agencies 2008 Clean Water Needs Study, the total cost of wastewater and storm water infrastructure need in the US is 298.1 billion dollars, 192 billion of which is needed for wastewater treatment. Though limited funding exists for clean water infrastructure in most cities, reliance on traditional and costly centralized impervious "gray" infrastructure persists despite its limited ability to improve water quality [24].

With the need for replacement there now exists an opportunity for multiple professions to contribute to newer greener types of infrastructure that are inclusive of the ecosystem services that sustain human habitats and protect sensitive species in an ecological mutual paradigm. It is possible to plant the "green" of green infrastructure to support biodiversity and ecosystem resiliency. This new type of infrastructure can contribute to environmentally sensitive remediation and development. A multi-layered approach to infrastructure using land-based strategies could effectively address multiple problems simultaneously while reducing energy needs, pollution stress and infrastructure costs.

\section{Strategies for Biodiversity Conservation and Green Wastewater Infrastructure}

In the last few decades a new paradigm has emerged in urban storm water management, shifting our storm water infrastructure from large scale centralized capture and release conveyance systems to a smaller-scale, decentralized practices modeled according to principles of low impact design (LID) and best management practices (BMPs) that filter and infiltrate polluted storm water closer to the source. Low impact design practices seek to mimic pre-development conditions based on naturally occurring hydrology while BMPs exist as decentralized green infrastructure treatment facilities at the scale of blocks or singular buildings. If land based systems similar to common LID practices and BMPs are to be used to treat wastewater, the scale of such systems is of particular importance, especially in dense urban environments where public greenspace is at a minimum. 
Land sparing is the conservation technique of setting aside land outside of human development for nature reserves [25]. It is considered by a 2015 study to be the best option for preserving habitats necessary for the survival of the largest variety of species on the planet [7]. As the population of the world's cities grows, strategies for development that involve minimal impact on local ecosystems are vitally important. In a typical land sparing configuration, extremely compact intensive urban growth is separated from large contiguous conservation lands. Landscapes designed for human activity that simultaneously provides wildlife with habitat is referred to as land sharing. Land sharing in an urban context provides significant public health benefits while cultivating public understanding and sympathy for biodiversity losses and the goals and imperatives of conservation [7]. In the case of wastewater management, centralized systems are compatible with a land sparing approach. Wastewater treatment in urban areas of the US overwhelmingly consists of large-scale, extensively piped conveyance systems with centralized treatment facilities. Alternatively, wastewater treatment performed in decentralized systems of more numerous smaller-scale treatment facilities is more compatible with a land sharing model.

A 2014 study conducted by research ecologists evaluated Rio de Janeiro, Brazil and Portland, Oregon evaluated the ecosystem benefits of land sparing (Rio) and land sharing (Portland) models. The Rio model of a dense urban area surrounded by large tracts of natural land performed a better job of sustaining ecosystem services including cleaning water and air, reducing noise, supporting pollination and storing carbon. The same study found in densely urbanized areas, land sparing resulted in greater population sizes for the majority of species studied. The model of land sparing was also found to do a better job of mitigating the urban heat island effect [26]. The researchers found development occurring at moderate levels such as that in suburbs causes natural lands to lose their ability to provide ecosystem services at a far greater rate than denser developments [27]. It is recommended by the researchers that City planners and policy makers adopt land sparing strategies in areas that will be densely urbanized in the future, by leaving large blocks of greenspace undeveloped [26].

Close to half of the population of the world lives in "highly modified human dominated landscapes", that are growing even more disconnected from nature. Worldwide forty percent of people live in urban regions and that number is expected to increase to sixty percent by 2030. Without access to the natural world, city dwellers suffer from what ecological researcher James Miller calls an "extinction of experience" that comes with severe risks to human health. Beyond public health, a lack of experience of biodiversity can lead people to disaffection and apathy towards nature. Childhood experiences are particularly important to combat the origins of estrangement from the natural world [28]. Land sharing regions such as Portland that offer residents many small public parks gave residents a greater sense of well-being and improved mental health, according to the 2014 study of Rio de Janeiro and Portland. Use of public greenspaces and satisfaction with those greenspaces was found to be higher in land sharing regions [26]. Emphasis on land sparing could decrease human-nature interactions, negatively affect public health outcomes and reduce public interest in biodiversity by limiting access. In the midst of rapid urbanization, development and infrastructure retrofitting designs that preserve biodiversity and minimize negative impacts on local species are an urgent matter [26]. Biodiversity enhancing strategies need to be carefully planned within urban areas to achieve measurable conservation benefits. According to researchers in the Department of Biology of Lund University in Sweden, land sparing could be executed simultaneously at multiple spatial scales to the greatest effect for local biodiversity. With appropriate planning, conserving smaller scale areas for habitat may better facilitate the movement of species between habitat fragments and provide greater resources to nomadic species [29].

The scale and distribution of wastewater treatment systems presents a complicated challenge for local ecologies. Wastewater in most major urban cities in the United States is ideally treated by the piping of flushed effluent to large-scale centralized, energy consumptive wastewater treatment plants that release treated effluent to adjacent water bodies. In the centralized systems of areas with varying topography, energy intensive pumping stations are in necessary for conveyance structures 
to traverse changing elevations en route to a limited number of treatment plants. Though significant technological advancements have been made in wastewater treatment plants in the United States, economic constraints, remain a barrier to major improvements in financially distressed urban areas such as Baltimore, Maryland [30]. Due to the deterioration of century old pipes that make up conveyance structures, storm water infiltration is a major contributor to sanitary sewage overflows. To control sewage overflows due to heavy storm water inundation, the US cities Chicago and Milwaukee have dug deep tunnels into bedrock over three hundred feet below ground in order to hold and convey sewage overflows in massive temporary holding quarries. These deep tunnel systems allow for better overflow storage in increasing heavy rain events brought about by climate change. However, significant pumping is necessary to move water stored in deep tunnels back to ground surface and the deep tunnel system requires highly dangerous construction and maintenance work [31].

Decentralized wastewater management systems are those that collect, treat and discharge or reuse wastewater at or near the point of origin as opposed to relying on extensive conveyance networks. In rural areas of the US and in some developing countries and towns such as Mobile, Alabama decentralized wastewater treatment strategies have been implemented as economically feasible and environmentally sustainable solutions to local small-scale wastewater management. In sparsely populated areas of developing countries, decentralized treatment can provide cost effective alternatives to extensive sewer pipes and systems [32]. In the United States, twenty-five percent of the population is served by decentralized wastewater treatment systems [18]. Wastewater treatment essentially consists of collection, treatment and disposal. In centralized systems, especially in countries with low and sparse population density, sixty percent of the total wastewater treatment budget goes to collection costs [32]. Onsite or neighborhood scale wastewater treatment systems offer an opportunity to capture and treat waste closer to the source within the built environment, reducing the need for conveyance structures and minimizing related retrofits [33]. While a smaller-footprint centralized treatment plant may seem to require less land than multiple and potentially more land-intensive decentralized green treatment systems, the methods and scale of conveyance are a necessary part of the central structure. Centralized treatment may seem to operate as a land sparing method in terms of land use, however the frequent failures of their extensive subterranean conveyance structures have result in deleterious environmental impacts to vulnerable shared habitats. Appropriate placement and design of green infrastructure wastewater treatment systems is critical to supporting remaining habitat fragments within treatment sites.

Constructed wastewater treatment wetlands typify low impact land-based filtration and green infrastructure design, allowing for multiple beneficial environmental and anthropogenic functions. Unlike their predecessors, storm water ponds, constructed wetlands filter and remediate pollutants instead of just containing overflows. Constructed wetlands treat polluted domestic or industrial wastewater using plants and engineered soils. They mimic natural filtration processes with native vegetation, soils and microbial communities. Design of these systems involves variable criteria including: wastewater constituents, plant species, substrate materials, flow direction and retention times [34]. Constructed wetland systems for wastewater treatment can be land-intensive, according to some estimates: a system for wastewater from 10,000 persons requires twenty acres of land [35]. However, recent advances in wastewater treatment methods such as using "biohedge" matrices to grow decomposing microbes can reduce land-intensiveness of such treatment systems [36]. Biochar, a byproduct of agricultural biomass waste, was found by researchers at Kwandong University in Korea to greatly enhance constructed wetland function due to its highly porous structure and low economic investment. When used as a soil amendment Biochar effectively absorbs heavy metals, remediates contaminants, improves fertilizer retention and increases hydraulic capacity in constructed wetlands [37]. Novel design of constructed wetlands can also make use of adjacent natural wetlands as a final polishing treatment beds for wastewater coming from pretreatment systems. Excessive nutrients in wastewater are remediated by plant communities in the natural wetland, providing nutrients that can have a positive impact on growth rates, resulting in a mutually beneficial relationship [38]. 
Constructed Wetland treatment systems have the potential to function compatibly with land sharing conservation methods if treatment wetlands are designed to have multiple functions as educational centers, recreational parklands and wildlife habitats. Careful analysis of multiple environmental, economic and social factors is necessary to address the scale and placement of such systems and any proposed land based retrofits to existing water infrastructure.

\section{Potential Benefits of Green Wastewater Infrastructure}

Purified, potable water clean enough to wash a baby is currently used for flushing our toilets, watering our gardens and washing our vehicles. The energy cost of conveying and treating wastewater is one of the largest consumers of energy in most municipalities and a major contributor to carbon emissions in the United States [11]. Though it may not seem so, raw sewage is composed of 99\% pure water. Roughly half of wastewater is from toilets, the remaining half: called "greywater" comes from sinks, bathtubs, showers and washing machines [17]. Treatment processes in systems such as constructed wetlands are far less energy intensive, use fewer chemicals for disinfection, create less toxic sludge as a treatment byproduct and landfill waste and emit less greenhouse gases through construction and operation compared to standard treatment methods [33]. Greywater, water that has not come into contact with human waste, can be recycled for non-potable reuse on building sites or purified in onsite treatment facilities. A combination of composting toilets and greywater treatment through constructed wetlands is ideal for new developments, operating onsite with a low energy footprint. However, constructed wastewater treatment wetlands for small sites could potentially carry a larger footprint and require better soil drainage than is possible for dense urban areas. Installation of such systems would depend on the actions of existing building owners, zoning and developers. A system will be necessary in most urban areas to continue to treat wastewater coming from existing conveyance networks even as newer developments are incentivized to incorporate LEED methods of wastewater management, storage and reuse with the ultimate goal of reducing wastewater production and potable water usage. A move toward green infrastructure that supports natural filtration processes of the hydrologic cycle is essential to the protection of public health and clean water resources. There is a need for green space in human dominated landscapes to influence greater understanding of the necessity of conservation efforts [26]. Exposing communities to the processes and pitfalls of contemporary clean water infrastructure has multiple potential benefits: behavioral changes, stewardship and development of interest in research and participation in clean water complexities. Addressing cultural barriers affecting public acceptance of green infrastructure systems requires education to change our understanding of waste management and to overcome discomfort with unfamiliar treatment systems such as composting toilets [33] and (potentially) greenspaces that support wildlife while treating wastewater.

The ecologist E.O. Wilson described biophilia as the innate human tendency to seek out novel and diverse organisms and to explore and associate with other living things. Biophilia is a significant and formative process of our mental development [39]. Biophilic design is a strategy in landscape architecture that seeks to mimic natural systems in order to reconnect humans to nature in urban environments. Land based wastewater treatment systems have the capacity to foster our innate love of nature while promoting environmental stewardship and public understanding of conservation needs and practices through education and direct experiences with diverse ecosystems [27]. Interaction with the natural world through urban greenspaces provides multiple public health benefits to city residents. Public greenspaces are importance for facilitating social capital, the value of collective social interaction in people's lives. Lack of social capital is as major a factor in determining health and mortality as smoking and obesity are. The amount of greenspace accessible in one's environment is a major predictor of mental health status among residents, when factoring in both the benefits of physical activity and of social cohesion. The amount of public green space in communities is positively associated with lower body mass index (BMI) in children along with reduced odds of BMI increases over time. Physical activity early in life is critical to creating sustaining physical activity in adulthood. Parks in urban 
environments at least two and a half acres in size have significant effects on reducing air temperatures, lowering the risk of heat related illnesses exacerbated by the urban heat island effect. Consistent and accurate reporting on the health co-benefits of green infrastructure would promote its necessity as a fundamental public health practice [40]. Urbanization and lack of green space is associated with increased incidences of depression and mental illness. A longitudinal study from researchers at the European Centre for Environment and Human Health in 2014 reported significant and sustained gains in mental health following relocation to greener areas. Researchers in environmental science, biology, neurology and psychology at Stanford University report walking through a natural area affects the brain in meaningful ways walking for the same duration through an urban environment does not. The Stanford study found walking in a natural setting markedly decreased levels of rumination (commonly referred to as brooding) in participants, suggesting a powerful connection between greenspace and mental well-being [41]. Urban environments cause attention fatigue as a result of required sustained directed attention on a greater variety of sensory input. The ability of natural environments to ameliorate symptoms of mental fatigue has positive effects on symptoms of Attention Deficit Hyperactivity Disorder, both improving concentration and self-discipline. Greater access to natural environments can provide urban residents with an opportunity to recover from attention fatigue and improve cognitive function. By planning urban landscapes to address a lack of available greenspace, green infrastructure has the capacity to function as public greenspace with associated ancillary benefits to public and ecosystem health. People are attracted to both constructed and preserved wetlands for a variety of reasons, often to relax and observe wildlife [17]. Preserved wetlands such as intact marshland provide critical habitat for many species. Coastal Marshes and tidal wetlands provide habitat for native nesting and migratory birds, including great blue herons, snowy egrets and the American oystercatcher. Shoreline and upstream development are the greatest threats to tidal wetlands, adding excess sediment and nutrients to tributaries that blocks photosynthesis and degrades wetland habitat [42]. Increasing the resiliency of shore habitat is critical to providing a natural buffer from storm surges as tidal habitats become further fragmented due to sea level rise. A recent report issued by the evidence-based collaborative research group, Science for Nature and People Partnership (SNAPP) used advanced flood modeling to determine the direct impact of coastal wetlands had on annual property damage from storms. They looked at data from two thousand storms in New Jersey, US to determine the effect shoreline wetlands had on property damages. The study found shoreline wetlands reduce annual property damages by over twenty percent, a significant reduction in vulnerable areas. On the Atlantic coast of the US, wetlands saved an estimated \$625 million in damages caused by Hurricane Sandy (2013), the second costliest hurricane in US history [43].

The intention of using constructed wetlands as water treatment facilities is to meet water quality imperatives with minimal disturbance to existing wildlife populations [17]. At this time, a small number of constructed wetlands have been designed with the specific intention of contributing to wildlife conservation. Barriers to design that prioritize wildlife conservation potential are: lack of understanding of ecological and conservation principles and needs, added costs, dearth of design manuals that could outline design techniques and lack of clear and obvious benefits to local communities. Effluent coming from surface flow constructed wetlands already contains a fundamental part of the wetland food chain and has less negative environmental impact on surface waters when discharged [20]. In some cases when treatment wetlands feed nutrient-rich effluent to tertiary wetlands, the treatment wetland acts as a nutritional support system for an already established and bio-diverse wetland habitat [17]. Constructed wetlands can be designed and managed to optimize wildlife and biodiversity potential in urban areas. Projects enacted to enhance biodiversity in the urban environment need to take into account the habitat value possible within the context of a densely built environment. Conservation studies and practices are generally species specific and management that increases populations of one species may not be effective for another [44]. Designers, engineers and land planners need to intentionally collaborate with conservation biologists and ecologists to restore and retrofit existing native habitat for species that are expected to gravitate due to warming 
temperatures [45]. Areas of treatment wetlands may need to be separated from human contact by design in order to promote wildlife conservation goals and protect public safety.

The use of constructed wetlands to treat urban wastewater has both potential positive benefits along with complicated design challenges of scale, siting, design and systemic cohesion. Careful implementation and design of green infrastructure for wastewater is imperative to protect public and ecosystem health in a manner feasible for large urban populations. Positive effects of replacing gray infrastructure with green infrastructure are evident in enhances to ecosystem services that benefit human populations and support habitat for dwindling native species. In urban regions, greenspace and green infrastructure can mitigate negative effects of human development by mimicking natural hydrologic processes. There is potential for large treatment wetlands to develop into important habitat, even if the system itself becomes obsolete in time. For example in Toronto, Canada, a barrier island called The Leslie Street Split unintentionally evolved, following decades of neglect, from a construction waste fill project in the 1950s into a designated and protected wildlife reserve. The Leslie Street Split now exists as a public educational park, wildlife habitat and barrier island protecting Toronto from shoreline erosion [46].

\section{Case Studies of Wetland Wastewater Treatment Facilities}

The use of constructed wetlands to treat urban wastewater has both potential positive benefits along with complicated systemic design challenges. Despite these challenges, some municipalities have been able to construct or retrofit wastewater treatment systems with constructed wetlands with successful outcomes. In order to understand the potential of constructed wastewater treatment wetlands to enhance and protect biodiversity, a closer look into diverse existing wastewater treatment systems is necessary. The following case studies contrast existing constructed treatment wetlands systems with an example of a wastewater treatment system typical in urban areas of the United States as a method of better understanding feasibility issues effecting the implementation and long-term sustainability of green wastewater systems.

\subsection{Existing Urban Wastewater Treatment Plants: Baltimore and Surrounding Counties, Maryland (1860s-Present)}

A sewage commissioner was appointed in 1859 in the city of Baltimore following the discovery by John Snow that correlated sewage contamination of drinking supplies to outbreaks of infectious disease. In nineteenth century urban American cities, citizens dumped their human waste into private cesspools that were later emptied out by "night soil" workers, a major industry at that time. The night soil industry lobbied against the sewage commissioner's plans to construct a new massive centralized underground sewer network like the systems constructed overseas [47]. Since the private sewage cesspools of the regions upper classes were the known cause of sewage contamination in drinking water, the new sewage commissioner's plan included the installation of conveyance structure networks connecting all areas of the city. Wealthy residents feared the pipeline connection to the lower classes and protested against a so-called "two-way pipe" that would cause the gaseous "germs" of the lower classes to backflow into the bathrooms of the upper class [48]. After the destructive force of the Baltimore Fire in 1904 left many areas in dire need of repair, Baltimore city mayor Robert McLane made moves to erect the modern wastewater infrastructure the city depends on for wastewater treatment today [47].

Baltimore's current wastewater treatment system consists of two major treatment plants located on the Chesapeake Bay: Back River and Patapsco. The entire system treats two hundred and ten million gallons of wastewater on an average day. Both treatment plants can treat up to two hundred and fifty million gallons of effluent per day, according to the Baltimore Department of Public Works. Nearly 3100 miles of sanitary sewer conveyance infrastructure collect effluent from Baltimore City and Baltimore County, 1400 miles of which are located in Baltimore City. Eight major and ten minor pumping stations convey wastewater to the two centralized treatment plants located on the shoreline 
of the Chesapeake Bay [49]. Heavy rains falling in the region frequently contribute to sewage overflows that release into urban streams and storm drains. As described by a journalist at the Baltimore Sun: "Whenever the rain pours-and even when it doesn't-the city's streams and harbor are contaminated by raw human waste spilled from corroding, porous sewer lines [to such an extent] that it's unsafe in most places for people to swim or wade." In the inner harbor, a major site of local tourism where people enjoy small boats and kayaks, safe levels of fecal bacteria are reported only 35 percent of the time. Sewage overflows affect homeowners when systems back up into basements [1]. According to the Baltimore Department of Public Works 7500 homes were flooded with raw sewage just in the last 9 months of 2017. The city does not compensate damages to homes from overflowing sewage, leading to lawsuits that cost the city thousands of dollars. Sinkholes caused by the collapse of massive underground sewage pipes have been opening up on the eastside of the city since the late nineties. When these large pipes collapse, other lines of infrastructure sink down into the sinkhole created. In 1997 a collapse in the sewage infrastructure collapsed gas and electric lines causing an inferno that destroyed the streetlights and a couple of buildings. The seventy to eighty-year-old system is not considered adequate to support the loads demanded on it today, nor the population and climate pressures of the future. The environmental nonprofit The Environmental Integrity Project released a study in 2015 detailing the extent of the environmental issues facing upgrades to the severely deteriorating system. A 2002 consent decree between the city of Baltimore and the United States Environmental Protection Agency (EPA) required the city pay a $\$ 600,000$ penalty for the recurring and illegal dumping of millions of gallons of raw sewage. An agreement was made to overhaul the system and eliminate all illegal sewage overflows by 1 January 2016. Following the decree, the city tripled water and sewer bills, collecting around two million dollars from city residents since 2002 for infrastructure improvements and standard operational cost. Seven hundred million dollars went into sewage infrastructure improvements between 2002 and 2015 with major projects ongoing over the last thirteen years and the city is only half completed with necessary upgrades as of late 2017. In the year 2015 approximately forty million gallons of raw sewage reportedly overflowed, likely far less than the actual amount due to the underreporting by the city. Overflows of less than 10,000 gallons do not even require public disclosure to the regions citizens, even when they occur in highly populated areas frequently traversed by citizens, such as the Jones Fall (Greenway) Trail. Between 2009 and 2013 the city broke the terms of the consent decree 1258 times, resulting in fines of around $\$ 830,000$ paid in addition to yearly fines already imposed by the EPA [50].

The Back River treatment plant is located on the west shore of the Back River branch of the Chesapeake Bay in Baltimore County, Maryland. It occupies four hundred and sixty-six acres and allows influent to move entirely via gravity due to a designed thirty-five foot elevation change. Close to 1.3 million regional residents living within one hundred and forty square miles are served by the Back River plant [49]. The Back River Treatment Plant is officially one hundred and four years old and suffering from a major problem with a pipe misalignment, severely limiting the plant's ability to handle large rains. Increasing periods of heavy rainfall have led to the release of millions of gallons of raw sewage into the Jones Falls Stream, a tributary that empties into the Chesapeake Bay. The Jones Falls Stream runs adjacent to the Jones Falls Trail, a local greenway popular with cyclists and runners. Bids to build a 36 million gallon holding tanks to temporarily store waste during heavy storms were currently under way as of October 2015 [1]. A massive four-acre orb-web, created by a diverse habitat of spiders was found in the rafters of Back River treatment plant's sand filtration tanks. Spiders are synanthropic species that thrive in built environments, in this case flies in the water provided energy to the spiders without the presence of a predator or competition for resources. They thrive in some treatment plants that have biofilters that host small invertebrates and structures that provide shelter, where they exist in numbers that far outweigh their populations in their native marshlands. The spider population is considered harmless and will be allowed to remain, however repairs are necessary to counteract the weakening effect their webs have on steel ceiling supports. Their population explosion is indicative of species persistence even in barren, built environments [51]. While novel, the spider 
population indicates an ecosystem out of balance, supporting the rapid proliferation of a single dominant organism type. This is indicative of an ecosystem that lacks a diverse enough variety of species to control excessive population growth.

Patapsco wastewater treatment plant was built in 1918 when the city of Baltimore acquired an extra sixty square miles, leading to a larger area in South Baltimore that was without sewage treatment facilities. The Patapsco plant services effluent conveyed from the Gwynn Falls watershed and the Patapsco river basin, treating nearly sixty-three million gallons per day and servicing around four hundred and fifty thousand people in one hundred and eighty square miles. The site of the plant is on approximately sixty-nine acres at Wagner's Point [49]. The facility failed to adequate meet the state's pollution limits in 2014, leading to a $\$ 5000$ fine and a two-year extension for necessary nutrient removal upgrades [30]. After a near-record downpour in April 2014, the Patapsco plant released more than three million gallons of raw sewage into the Patapsco River [1].

Large centralized wastewater systems are arguably valuable as land-sparing entities when compared with land intensive wastewater wetlands. However, their reach is extensive when we include the vast underlying infrastructure network of conveyance pipes and pumping stations necessary to transport waste to centralized treatment structures. With further human development and increasingly heavy rains prevalent in a changing climate, storm water infiltration of deteriorating sewage infrastructure will intensify leading to greater and more frequent sewage overflows in many urban areas.

\subsection{Arcata Marsh and Wildlife Wetlands: California, United States (1986-Present)}

The Arcata constructed wastewater wetland performs wastewater reclamation and treatment in a semi-rural small town-scale constructed wetland wastewater treatment system serving a population of around fifteen thousand people. The treatment wetland is located on a 154-acre site in Northern California, two hundred and eighty miles north of San Francisco. In the 1970s point source pollution coming from the regions existing treatment plants led city officials to a proposal for a new centralized treatment system intended to treat wastewater coming from Arcata and the entire Humboldt Bay region. Projections of the regional plant showed significant cost and operational demands while organizational difficulties with surrounding communities delayed progress. To sway public opinion, city officials along with researchers conducted experiments with novel wastewater and constructed wetland treatment systems. From their experiments, they determined constructed wetlands would be sufficient to treat wastewater while contributing to the biological productivity of the existing wetland ecosystem. Estimates show Arcata's portion of the centralized treatment plant would have cost approximately $\$ 10$ million as opposed to the $\$ 5$ million spent to retrofit the existing plant with treatment wetlands, a major factor in swaying Arcata officials. The maintenance costs of the system are $\$ 500,000$ annually compared to the $\$ 1.5$ million that a centralized plant would have required. The existing Arcata wastewater wetland has now been functional since 1986. The system has met water quality standards while demonstrating the ability of marsh plants, soils and microorganisms to treat municipal wastewater with nominal negative environmental impacts and reduced energy, maintenance and operational needs. The system proved useful for the rearing of native fish species and provides crucial habitat for native species including migratory birds along the pacific flyway. Support and protection of existing local wetlands helped reverse the trend of wetland habitat loss in the region. The site surrounding the existing Arcata treatment plant included nearly forty acres of abandoned brownfields and former wetlands that blocked shoreline access. The restored site now provides shoreline access to the community and an innovative recreational and educational interpretive center. The transformed marsh is now called the Arcata Marsh and Wildlife Sanctuary (AMWS) due to the diversity of the wildlife habitat it supports, including: aquatic species, shorebirds, waterfowl, migratory birds and raptors. Nearly 200 bird species utilize the marsh as a resting place or home. Nature walks along with school and visitor tours are conducted at AMWS. The park is visited by more than one hundred and fifty thousand people every year for passive recreation, art inspiration, scientific 
research and bird watching. The City of Arcata was awarded funding from the Ford Foundation to build an interpretive center that focuses on educating visitors on the scientific, biological and technical components of the system [17]. The Arcata treatment wetlands are an example of a successful wastewater treatment that positively impacts residents of the region, providing a multiple economic and social benefits beyond just standard and effective treatment of waste. The marsh functions simultaneously as infrastructure and habitat, further evolving to suit the needs of humans and wildlife. The proven success of a cost saving retrofit to what was previously a poorly functioning system provides a strong argument for the implementation of similar systems in other municipalities.

\subsection{EcoSistema Filtro (ESF) of the Parco Naturale Regionale Molentargius-Saline, Sardinia, Italy (2004-Present)}

The EcoSistema Filtro (ESF) is a nine hundred and fifteen acre wastewater treatment wetland constructed in 2004 within Molentargius-Saline Nature Reserve of Sardinia, Italy. The MolentargiusSaline reserve was established in 1999, between two fast-growing urban cities in Italy: Quartu Sant'Elena and Cagliari. The ESF was financed by the Environmental Ministry of Italy as a part of the Molentargius protection plan for the reserve. The ESF is a constructed wetland that provides secondary treatment to effluent coming from the Is Arena Depuration Plant in Cagliari. Following treatment, the ESF supplies purified and bio-chemically balanced water to restored freshwater ponds in the nature reserve. The proximity of the reserve to the two cities that surround has provided an ideal opportunity for educational and recreational activities that are easily accessible to the local population. The park dedicates educational walking tours on the topic of constructed wetland purification processes and the importance of wastewater reuse. It offers recreational activities such as rare bird watching. Ecologists use the site to tag and monitor birds. Some of the reserves research activities are open to public attendance and small groups are invited to assist biologists and naturalists. Though publically accessible, the wetland is carefully managed to prevent negative effects of human interaction by limiting volunteer numbers and human contact as needed to protect the habitat. The Sustainability and Environmental Educational Centre of Molentargius (CEAS) introduces visitors to the ESF and provides didactic texts, audio-visuals, educational project space and amenities for events. The ESF has developed in just the last decade into an important habitat for a variety of vulnerable native species of plants and animal including many waterfowl. A study performed by Italian botanical and conservation researcher began recording a floristic survey of plants in the ESF in 2005 one year after the plant was first constructed. Following the years 2006-2007 researchers have recorded a continuous development of species richness with increases in native species, threatened species and alien species. Native species have persisted strongly in the wetland, a positive indication of successful species conservation long-term. The persistence of native flora indicates quality habitat for native non-plant species such as lepidoptera, birds and aquatic species that compose the important trophic foundation of the wetland food chain. The success of the ESF shows great potential for artificial ecosystems to preserve and enhance biodiversity with in a peri-urban context. Ancillary benefits of the Ecosistema Filtro to surrounding human communities include clean water, educational activities and ecotourism [52].

\subsection{Wastewater Treatment Facilities: Cannon Beach, Oregon (1980s-Present)}

In 1982 the city of Cannon Beach, Oregon received approval for a plan to use constructed lagoons and wetlands to support wastewater treatment in an existing wooded wetland, in order to meet new and stricter regulations enacted by the Clean Water Act of 1972. Though the permanent population of the town of Cannon Beach was only around sixteen hundred, the system was designed to handle population increases during the summer tourism season. The system treats one hundred and eighty million gallons a year, meeting strict effluent standards from the United States Environmental Protection Agency. The treatment system is comprised of thirteen miles of sewage conveyance pipes, nine pumping stations, an analysis laboratory and a series of lagoon and wetland treatment cells. Twelve and a half acres of facultative lagoons and two aerated lagoon cells and sixteen acres of 
wetlands comprise the multistage system. Wooded wetland cells serve as a polishing system before treated effluent is discharged into Ecola Creek. In the summer months shade from surrounding trees inhibits algae growth. A natural wetland was altered using dykes to contain water control structures, allowing for minimal alteration to the existing ecosystem. The cost of the system in 1985 was 1.5 million dollars, eighty percent of which was funded by a grant from the Environmental Protection Agency. The operating costs of the system represented just twelve percent of the total sewer department's budget from 1992 to 1993 . Only one full time staff and two part time staff are needed to operate the wetlands and perform lab work. The system does not produce offensive odors and contributes to a development pattern that is not disruptive to the surrounding environment. The treatment system was maintained to meet greater demands approximately a decade after installation by dredging sludge from lagoons and improving aeration methods. Other system improvements have included an ultraviolet disinfection replacing the need for chlorine disinfection, significant because the chlorine discharged from wastewater treatment plants distress aquatic habitats even in trace amounts. The Cannon Beach treatment wetlands have effectively reduced the volume of city effluent discharges to Ecola Creek, improving overall water quality and habitat in the riparian zone. Civic involvement in the project has heighted awareness of the city's ecological and geographical context and issues related to water infrastructure. The site is used for study by the local school system and nature tours are organized for various citizen groups [17].

The Cannon Beach wastewater wetland system is an example of ecologically sensitive integration of wastewater infrastructure into a surrounding landscape. It has demonstrable economic, recreational and educational benefits to permanent and seasonal residents of Cannon Beach. Ancillary benefits to the local ecosystem include habitat creation and the protection of existing wetlands from destructive development practices. The add-on improvements exemplify the flexibility the system possesses in its ability to incorporate newer treatment technologies while maintaining effective outcomes.

\section{Towards a New Wastewater Paradigm}

In many urban areas of the United States sewer treatment systems are ticking time bombs, sporadically hemorrhaging evidence of a large-scale infrastructure crisis below our feet. For decades investment in anthropogenic structures that house and convey human beings throughout the landscape have outpaced maintenance of structures conveying less economically productive necessities. The United States American Society of Civil Engineers estimate nine hundred billion gallons of sewage water teeming with destructive nutrient and chemical pollutants spill every year from miles of failing wastewater treatment systems. Multiple sinkholes have appeared in cities like Baltimore as sewage pipes woefully past their usable lifetimes collapse below city streets [53]. Orchestrating the vast repairs necessary to maintain our ecosystems is a complicated imperative, however essential to preventing further casualties of inadequate sanitation.

Wetlands cover $5-8 \%$ of land worldwide. Nearly half of the wetlands in the United States have been destroyed as of 2015 and we lose nearly sixty thousand acres yearly [54]. Only in the last fifty years have the public and policy makers begun to recognize the vital ecosystem services wetlands provide. Numerous wetlands were drained and cleared prior to the 1960s, when they were considered disease-harboring garbage "swamps" devoid of value [55]. These bogs and wet seams where land meets water are where the highest concentration and diversity of life resides. A density of crabs, invertebrates, reptiles and fish are found and supported by these fertile habitats. Great blue heron, osprey, bald eagles and numerous species of birds rely on tidal wetland habitat for migrating, feeding and nesting. One third of wetland breeding bird species are considered highly or medium vulnerability to future effects of climate and development stressors [54]. From an anthropocentric perspective, tidal wetlands represent the most desirable tracts of waterfront real estate, as attractive to humans as they are to wildlife. Shoreline property is highly sought for its worth economically and valuable as a source of dilution waters used by shoreline wastewater treatment plants for effluent dilution. Shoreline development provides easy access to cooling waters for power plants and desirable 
spaces for boats in expanding marinas. Tidal marshes are considered highly vulnerable habitat by the United States Environmental Protection Agency, with significant losses along the Eastern coast of the United States [55]. Degradation of shoreline wetland habitat used by migrating birds since the 1970s has contributed significantly to the extinction of avian species. Conserving existing wetlands and implementing living shorelines that restore tidal ecosystems as an alternative to inflexible shoreline bulkheads is vital to restoring bio-diverse habitat and mitigating species extinction [56].

Our current water infrastructure paradigm exists on a continuum between destructive anthropogenic drainage systems and natural drainage systems wherein our anthropogenic systems are heavily prioritized. With wastewater treatment systems in urban areas of the US now at a crucial replacement age, there is an opportunity to develop new systems and retrofit existing systems to mutually benefit humans and other forms of life. Research and development of green infrastructure treatment systems exists in enough capacity to allow for collaboration between science, engineering and design fields to develop innovation in green wastewater infrastructure. As human populations and developments swell, flexible land-based systems can provide and protect habitat from destructive effects of ongoing urbanization and development. Wetland habitats that purify effluent can provide edge and riparian habitat and nesting sites for a multitude of species, enhancing long-term ecosystem diversity and stability. A new, resilient, ecologically mutual paradigm for wastewater treatment is imperative to benefit the long-term viability of human beings and native species. Increasing population size and progressive densification in urban areas means more pressure on existing systems to meet greater demands. Sea-level rise, climate change and predicted future water scarcities will all further limit the resiliency of our water infrastructure and the ecosystems we rely on to provide clean water. Reducing reliance on current energy intensive systems is crucial to maintaining long-term sustainability of treatment and conveyance systems [11]. Wastewater treatment in the United States currently accounts for 1.5 percent of all annual energy use [57]. Systems that require low-energy input and maintenance and those that contribute to energy production are highly desirable, economically and for long-term resiliency. Novel and ecologically mutual treatment practices can be implemented through green infrastructure with the capability to perform multiple functions in a low-impact, adaptable form [58]. The reuse of gray water along with storm water management practices of rainwater capture, treatment and infiltration can ideally constitute a large part of future water conservation efforts [11]. As a part of a network of sustainable water treatment practices, constructed wetland treatment parks can enhance human experiences of biophilia, provide educational experiences in conservation and ecology and improve public health. Wastewater treatment facilities have the potential to handle effluent treatment from urban areas while creating and maintaining habitat supportive of conservation efforts [10]. By embracing a clean water infrastructure paradigm that learns from and mimics naturally occurring land-based filtration processes we have the opportunity to repurpose large flows of wastewater as a valuable resource for enhancing biodiversity.

\section{Conclusions}

This paper demonstrates that: (1) wastewater treatment systems in urban areas of the US are in a state of disrepair leading to significant negative outcomes affecting human and non-human habitats; and (2) green wastewater infrastructure strategies that support native hydrology with positive environmental impacts are integral to the protection of the clean water humans and other species rely on for survival; and (3) The use of constructed wetlands in green wastewater infrastructure has great potential to ameliorate biodiversity losses in urban ecosystems while supporting and enhancing densely populated anthropogenic environments with multiple benefits to human health. Considering the scholarly gaps, further research is necessary to understand how land-based systems can replace or supplement current treatment infrastructure in practice, including implementation phasing and the remediation of existing brownfields necessary for transformation into healthy wetland ecosystems. Greater understanding of the bureaucratic processes influencing the development and implementation of green wastewater infrastructure as pertains to specific municipalities and any 
laws governing wastewater treatment practices is also needed to influence future developments in wastewater infrastructure.

Author Contributions: Caitlin Cunningham performed the review of literature and wrote the paper. Mohammad Gharipour provided guidance, feedback, review and editing.

Conflicts of Interest: The authors declare no conflict of interest.

\section{References}

1. Wheeler, T.B. No End in Sight for City's \$1.1 Billion Overhaul of Leaky, Polluting Sewers. Available online: http://www.baltimoresun.com/news/maryland/bs-md-sewer-overhaul-20150904-story.html (accessed on 13 December 2017).

2. Rabin, C.; Morgan, C. Miami-Dades Leaky Pipes: More than 47 Million Gallons of Waste Spilled in the Last Two Years. Available online: http:/ /www.miamiherald.com/2012/05/14/vfullstory/2799249/miamidades-leaky-pipes-morethan.html (accessed on 15 December 2017).

3. Tong, S. Baltimore Sewers: Time Bombs Buried under the Streets. Available online: https:/ /www.marketplace. org/2015/02/25/sustainability/water-high-price-cheap/baltimore-sewers-time-bombs-buried-under-streets (accessed on 11 December 2017).

4. Barber, S. Lake Erie's Toxic Algae Bloom Forecast for Summer 2016. Available online: http:/ / www.ecowatch. com/lake-eries-toxic-algae-bloom-forecast-for-summer-2016-1891172391.html (accessed on 20 November 2017).

5. United States Environmental Protection Agency. Harmful Algae Blooms \& Drinking Water Treatment. Available online: https:/ / www.epa.gov/water-research/harmful-algal-blooms-drinking-water-treatment (accessed on 3 January 2017).

6. Jorgensen, S.E. Water Quality: The Impact of Eutrophication. Lakes Reserv. 2001, 3, 1-25.

7. Soga, M.; Yamaura, Y.; Shinsuke, K.; Gaston, K.J. Land sharing vs. land sparing: Does the compact city reconcile urban development and biodiversity conservation? J. Appl. Ecol. 2014, 51, 1378-1386. [CrossRef]

8. Del Tredici, P. Wild Urban Plants of the Northeast: A Field Guide; Cornell University Press: Ithaca, NY, USA, 2010; ISBN 0801474582.

9. Rosenzweig, M.L. Win Win Ecology: How the Earth's Species Can Survive in the Midst of Human Enterprise, 1st ed.; Oxford University Press: New York, NY, USA, 2003; ISBN-10: 0195156048.

10. Smith, B.R. Re-Thinking Urban Wastewater Landscapes: Constructed Wetlands for Urban Ecological Mutualism in San Francisco. Master's Thesis, University of California, Berkeley, CA, USA, 2008.

11. Broaddus, L. Radio Interview by Susan Bence. All Things Considered, National Public Radio. Available online: https:/ /www.npr.org/programs/all-things-considered/ (accessed on 29 January 2018).

12. Brix, H. Treatment Wetlands: An overview. In Proceedings of the Conference on Constructed Wetlands for Wastewater Treatment, University of Gdansk, Gdansk, Poland, 11-12 November 1995; Toczylowska, I., Mierzejewski, M., Eds.; Technical University of Gdansk: Gdansk, Poland, 1995; pp. 167-176.

13. Lofrano, G.; Brown, J. Wastewater management through the ages: A history of mankind. Sci. Total Environ. 2010, 5254-5264. [CrossRef] [PubMed]

14. Benidickson, J. The Culture of Flushing: A Social and Legal History of Sewage; UBC Press: Vancouver, BC, Canada, 2007; ISBN 0774841389, 9780774841382.

15. Boone, C.G. Obstacles to Infrastructure Provision: The Struggle to Build Comprehensive Sewer Works in Baltimore. Hist. Geogr. 2003, 152-166.

16. Cutler, I. Chicago: Metropolis of the Mid-Continent; Southern Illinois University Press: Champagne, IL, USA, 2006.

17. United States Environmental Protection Agency. Constructed Wetlands for Wastewater Treatment and Wildlife Habitat: 17 Case Studies. Available online: https:/ /www.epa.gov/sites/production/files/2015-10/ documents /2004_10_25_wetlands_introduction.pdf (accessed on 3 January 2017).

18. Park, W.H. Integrated constructed wetland systems employing alum sludge and oyster as filter media for $P$ removal. Ecol. Eng. 2009, 1275-1282. [CrossRef]

19. Babatunde, A.O.; Zhao, Y.Q.; Zhao, X.H. Alum-sludge based constructed wetland system for enhanced removal of $\mathrm{P}$ and $\mathrm{OM}$ from wastewater: Concept, design, and performance analysis. Bioresour. Technol. 2010, 6576-6579. [CrossRef] [PubMed] 
20. Rousseau, D.P.L.; Lesage, E.; Story, A.; Vanrolleghem, P.A.; De Pauw, N. Constructed wetlands for water reclamation. Desalination 2008, 218, 181-189. [CrossRef]

21. Klettke, R. Phosphorus for Sale. Landsc. Archit. Mag. 2015, 10, 46.

22. Groves, C.R.; Game, E.T.; Anderson, M.G.; Cross, M.; Enquist, C.; Ferdaña, Z.; Girvetz, E.; Gondor, A.; Hall, K.R.; Higgins, J.; et al. Incorporating climate change into systematic conservation planning. Biodivers. Conserv. 2012, 21, 1651-1671. [CrossRef]

23. United States Environmental Protection Agency. Case Studies Analyzing the Economic Benefits of Low Impact Development and Green Infrastructure Programs; EPA841-R-13-004; United States Environmental Protection Agency: Washington, DC, USA, 2013; pp. A37-A45.

24. American Rivers; The Water Environment Federation; The American Society of Landscape Architects; ECONorthwest. Banking on Green: A Look at How Green Infrastructure Can Save Municipalities Money and Provide Economic Benefits Community-Wide; American Society of Landscape Architects: Washington, DC, USA, 2012.

25. Romnee, A.; Evrard, A.; Trachte, S. Methodology for a stormwater sensitive urban design. J. Hydrol. 2015, 530, 87-102. [CrossRef]

26. Soga, M.; Yamaura, Y.; Aikoh, T.; Shoji, Y.; Kubo, T.; Gaston, K.J. Reducing the extinction of experience: Association between urban form and recreational use of public greenspace. Landsc. Urban Plan. 2015, 143, 69-75. [CrossRef]

27. Stott, I.; Soga, M.; Inger, R.; Gaston, K.J. Land sparing is crucial for urban ecosystem services. Front. Ecol. Environ. 2015, 13, 387-393. [CrossRef]

28. Miller, J.R. Biodiversity conservation and the extinction of experience. Trends Ecol. Evol. 2005, 20, 430-434. [CrossRef] [PubMed]

29. Ekroos, J.; Odman, A.M.; Andersson, G.K.; Birkhofer, K.; Herbertsson, L.; Klatt, B.K.; Olsson, O.; Olsson, P.A.; Persson, A.S.; Prentice, H.C.; et al. Sparing Land for Biodiversity at Multiple Scales. Front. Ecol. Evol. 2016, 3-11. [CrossRef]

30. Ruetter, M. City Slapped with Small Fine, Given Two More Years to Complete Sewer Plant Improvements. Available online: https:/ / www.baltimorebrew.com/2014/12/24/ city-slapped-with-small-fine-given-twomore-years-to-complete-sewer-plant-improvements / (accessed on 25 October 2017).

31. Moser, W. Deep inside Chicago's Deep Tunnel. Available online: http://www.chicagomag.com/ChicagoMagazine/The-312/December-2011/Deep-Inside-Chicagos-Deep-Tunnel (accessed on 13 December 2017).

32. Massoud, M.A.; Tarhini, A.; Nasr, J.A. Decentralized approaches to wastewater treatment and management in developing countries. J. Environ. Manag. 2009, 90, 652-659. [CrossRef] [PubMed]

33. District Wastewater Management. Available online: http://ecodistricts.org/wp-content/uploads/2013/05/ Water_Manag1.pdf (accessed on 17 November 2017).

34. Upadhyay, A.K.; Bankoti, N.S.; Rai, U.N. Studies on sustainability of simulated constructed wetland system for treatment of urban waste; design and operation. J. Environ. Manag. 2016, 169, 285-292. [CrossRef] [PubMed]

35. Klockenbrink, M. Small Towns Build Artificial Wetlands to Treat Sewage. The New York Times, 29 November 1988.

36. Valipour, A.; Raman, V.A.; Ahn, Y. Effectiveness of Domestic Wastewater Treatment Using a Bio-Hedge Water Hyacinth Wetland System. Water 2015, 7, 329-347. [CrossRef]

37. Gupta, P.; Tae-woong, A.; Lee, S. Use of biochar to enhance constructed wetland performance in wastewater reclamation. Environ. Eng. Res. 2016, 21, 36-44. [CrossRef]

38. Doyle, T. Effects of Wastewater on Forested Wetlands. Available online: https://www.nwrc.usgs.gov/ factshts/104-02.pdf (accessed on 22 February 2016).

39. Wilson, E.O. Biophilia; Harvard University Press: Cambridge, MA, USA, 1984; ISBN 0674074424.

40. Coutts, C.; Hahn, M. Green Infrastructure, Ecosystem Services, and Human Health. Int. J. Environ. Res. Public Health 2015, 12, 9768-9798. [CrossRef] [PubMed]

41. Bratman, G.N.; Hamilton, J.P.; Hahn, K.S.; Daily, G.C.; Gross, J.J. Nature experience reduces rumination and subgenual prefrontal cortex activation. Proc. Natl. Acad. Sci. USA 2015, 112, 8567-8572. [CrossRef] [PubMed]

42. Wetlands. Chesapeake Bay Program. Available online: http://www.chesapeakebay.net/issues/issue/ wetlands\#inline (accessed on 20 December 2016).

43. Narayan, S.; Beck, M.W.; Wilson, P.; Thomas, C.; Guerrero, A.; Shepard, C.; Reguero, B.G.; Franco, G.; Ingram, C.J.; Trespalacios, D. Coastal Wetlands and Flood Damage Reduction: Using Risk Industry Based Models to Assess Natural Defenses in the Northeastern USA; Lloyd's Tercentenary Research Foundation: London, UK, 2016. 
44. Dearborn, D.C.; Kark, S. Motivations for Conserving Urban Biodiversity. Conserv. Biol. 2008, 24, $432-440$. [CrossRef] [PubMed]

45. Dance, S. Rare Pair of Tropical Birds Take Roost in Locust Point Drawing Birdwatchers. Available online: www.baltimoresun.com/features/green/blog/bs-md-brown-booby-20150921-story.html (accessed on 1 September 2017).

46. Belanger, P. Landscape as Infrastructure. Landsc. J. 2009, 28, 79-95. [CrossRef]

47. Woods, B. Sinkhole: What Is Happening Beneath the Ground Downtown? Baltimore Citypaper: Baltimore, MA, USA, 2016.

48. Puglionesi, A. The Manmade Marvel of the Baltimore Sewers. Atlas Obscura. Available online: http:/ /www. atlasobscura.com/articles/the-manmade-marvel-of-the-baltimore-sewers (accessed on 22 October 2016).

49. Bureau of Water and Wastewater. Baltimore City Department of Public Works. Available online: http: / / publicworks.baltimorecity.gov / Bureaus / WaterWastewater (accessed on 11 November 2015).

50. Pelton, T.; Bernhardt, C.; Burkhart, K.; Lam, S. Stopping the Flood Beneath Baltimore's Streets. Environmental Integrity Project Report. Available online: http:/ /www.environmentalintegrity.org/wp-content/uploads / 2016/11/FINAL-SEWAGE-REPORT.pdf (accessed on 3 January 2016).

51. Greene, A.; Coddington, J.A.; Breisch, N.L.; De Roche, D.M.; Pagnac, B.B., Jr. An immense concentration of orb-weaving spiders with communal webbing in a man-made structural habitat. Am. Entomol. 2010, 56, 146-156. [CrossRef]

52. De Martis, G.; Mulas, B.; Malavasi, V.; Marignani, M. Can Artificial Ecosystems Enhance Local Biodiversity? The Case of a Constructed Wetland in a Mediterranean Urban Context. Environ. Manag. 2016, 57, 1088-1097. [CrossRef] [PubMed]

53. American Society of Civil Engineers and The Economic Research and Development Research Group. Failure to Act: Closing the Infrastructure Investment Gap for America's Economic Future, 1-31. Available online: http:/ / www.infrastructurereportcard.org/wp-content/uploads/2016/05/2016-FTA-Report-Closethe-Gap.pdf (accessed on 30 November 2016).

54. North American Bird Conservation Initiative, U.S. Committee. The State of the Birds 2010 Report on Climate Change; United States of America; U.S. Department of the Interior: Washington, DC, USA, 2010.

55. United States Environmental Protection Agency. Wetlands Overview. EPA843-F-04-011a. 1-4. 2004. Available online: https:/ / www.epa.gov/sites/production/files/2016-02/documents/wetlandsoverview.pdf (accessed on 1 November 2017).

56. Horton, T. Turning the Tide: Saving the Chesapeake Bay; Island Press: Washington, WA, USA, 2003; ISBN 1610911164.

57. Logan, B.E. Research-BioEnergy, Overview of Microbial Fuel Cells, Pennsylvania State University. Available online: https:/ /www.engr.psu.edu/ce/enve/logan/bioenergy/research_mfc.htm (accessed on 21 February 2016).

58. Lovell, S.T.; Taylor, J.R. Supplying urban ecosystem services through multifunctional green infrastructure in the United States. Landsc. Ecol. Rev. 2013, 28, 1447-1463. [CrossRef]

(C) 2018 by the authors. Licensee MDPI, Basel, Switzerland. This article is an open access article distributed under the terms and conditions of the Creative Commons Attribution (CC BY) license (http:// creativecommons.org/licenses/by/4.0/). 